\title{
JUSTIÇA CONSENSUAL E A IMPOSIÇÃO DE SANÇÕES SEM O TRÂNSITO EM JULGADO ${ }^{1}$
}

\section{CONSENSUAL JUSTICE AND THE IMPOSITION OF SANCTIONS WITHOUT RES JUDICATA}

Flávio Mirza Maduro

Professor Associado do programa de Doutorado e Mestrado em Direito Processual e do curso de Graduação em Direito da UERJ, lecionando a disciplina Processo Penal. Professor Adjunto do programa de Mestrado em Direito e do curso de Graduação em Direito da UCP, lecionando a disciplina Processo Penal. Conferencista, palestrante ou colaborador de diversas instituições científicas e de ensino superior do País. Possui graduação em Direito pela Universidade do Estado do Rio de Janeiro (1999), mestrado (2002) e doutorado em Direito (2007), pela UGF, e pós-doutorado em Democracia e Direitos Humanos (Universidade de Coimbra). Rio de Janeiro/RJ. E-mail: flaviomirza@gmail.com

Tiago Lezan Sant'Anna Advogado do BNDES, Palestrante em matéria de Compliance, Processo Penal e Direito Penal Econômico. Membro Fundador do Instituto de Compliance Rio ICRio. Possui graduação em Jornalismo pela UFRJ (2004) e em Direito pela UERJ (2006), com Especialização em Direito Civil, Empresarial e Processual Civil (UVA/RJ), em Direito Penal Econômico (IBCCRIM/COIMBRA) e Residência Jurídica - Área Cível (UERJ). Mestre em

\footnotetext{
${ }^{1}$ Artigo recebido em 15/07/2021 e aprovado em 16/11/2021.
} 
Ciência Jurídicas pela Universidade Federal do Rio de Janeiro (2011) e Doutorando em Processo pela Faculdade de Direito da Universidade do Estado do Rio de Janeiro (atual). Rio de Janeiro/RJ.

RESUMO: Este artigo trata do sistema penal, analisando a constitucionalidade da imposição de sanções sem o trânsito em julgado da sentença. Sustenta-se a impossibilidade de o Poder Judiciário flexibilizar garantias constitucionais, assim como de o Poder Legislativo, em prol da eficiência do sistema, criar mecanismos que limitem o direito fundamental de liberdade e as garantias do devido processo legal e da ampla defesa. Discute-se a possibilidade de aperfeiçoamento do processo penal em direção a maior rapidez por meio de estímulo à justiça consensual.

PALAVRAS CHAVE: Processo Penal; garantismo; presunção de inocência; trânsito em julgado; justiça criminal negociada

ABSTRACT: This article deals with the Penal System, analyzing the constitutionality of the imposition of sanctions without the final judgment of the case. It is argued that the Judiciary cannot make constitutional guarantees more flexible, nor can the Congress create mechanisms that limit the fundamental right of liberty and the guarantees of due process and ample defense in favor of the efficiency of the system. The possibility of improving the criminal process towards greater speed by encouraging consensual justice is discussed.

KEYWORDS: Criminal Process; protection of civil rights; presumption of innocence; res judicata; negotiated criminal justice

\section{INTRODUÇÃO}

O processo penal vive uma tensão constante entre a necessidade de punir comportamentos delitivos e a tutela das liberdades individuais. 
Em especial nos crimes econômicos, a necessidade da chamada justa causa e a dificuldade na produção de provas, levam, muitas vezes, ao arquivamento de processos sem que o suposto autor do crime seja sequer instado a apresentar defesa.

Nos casos em que o processo chega a se constituir de forma plena, este fica, muitas vezes, restrito ao limitado objetivo de trazer ao juízo elementos para a formação do seu convencimento em relação à ocorrência ou não dos fatos alegados na denúncia ou na queixa.

Isto porque, em observância ao princípio do in dubio pro reo, caso o juízo não atinja um convencimento mínimo quanto aos fatos imputados ao(s) réu(s), ${ }^{2}$ impõe-se a absolvição ${ }^{3}$. No caso de condenação, após a sentença o processo pode ainda seguir para a fase recursal, muitas vezes demorada.

A longa duração dos processos ${ }^{4}$, aliada à aplicação do princípio da excepcionalidade da prisão antes da condenação definitiva, é frequentemente apontada como responsável por disseminar na sociedade a imagem de impotência do Poder Judiciário ${ }^{5}$.

Sem dúvida, a ineficiência do Sistema Penal também pode representar uma ameaça à tutela efetiva de direitos fundamentais.

Nesse contexto, a decisão do Supremo Tribunal Federal ${ }^{6}$ no sentido de que a execução provisória de acórdão penal condenatório proferido em grau de apelação, ainda que sujeito a recurso especial ou extraordinário, não comprometeria o princípio constitucional da presunção de inocência afirmado pelo artigo $5^{\circ}$, inciso LVII da Constituição Federal, veio a representar uma guinada em prol da operatividade repressiva.

No entanto, o STF acabou por reconhecer, conforme expresso no voto da Exma. Min. Rosa Weber no julgamento das Ações Declaratórias de Constitucionalidade

\footnotetext{
2 Brasil, D. R. A garantia do Princípio Constitucional da Presunção de Inocência (ou de nãoculpabilidade): um diálogo com os direitos e garantias fundamentais. Revista de Direitos Brasileira, São Paulo, v. 15, n. 6, pp.376-398, 2016.

${ }^{3}$ Soares, M. N. e Rorato, I. F. Garantia constitucional de presunção de inocência e a condenação penal em segundo grau, Revista de Direito Brasileira, v.19, n.8, p. 366-381, 2018.

${ }^{4}$ Lopes Jr., A. Direito processual penal e sua conformidade constitucional - v. 1. 17 ${ }^{\mathrm{a}}$. Ed. Rio de Janeiro: Lumen Juris, 2007.

${ }^{5}$ Rosa A. M. e Silveira Filho, S. L. Medidas compensatórias da demora jurisdicional: a efetivação do direito fundamental à duração razoável do processo penal. Rio de Janeiro: Lumen Juris, 2014.

${ }^{6}$ HC126.292/SP - Plenário - Rel. Min. Teori Zavascki - por maioria - j. 17/02/2016 (DJE no 32/2016).
} 
(ADC) 43, 44 e $54^{7}$ que, embora a sociedade tenha razão em exigir que o processo penal seja rápido e efetivo, problemas e distorções decorrentes das normas penais, como o tempo entre a abertura do processo e o início do cumprimento da pena, "não devem ser resolvidos pela supressão de garantias, e sim mediante o aperfeiçoamento da legislação".

Neste estudo, após discutirmos as características do processo penal clássico, será analisada a controvérsia em torno da prisão antes do trânsito em julgado. Em seguida, analisaremos a tendência de ampliação das possibilidades de aplicação de soluções consensuais, tais como a transação penal e a suspensão condicional do processo, previstas na Lei 9.099 de 1995, a previsão do artigo Art. 28-A, acrescentado ao Código de Processo Penal (CPP) vigente pela Lei 13.964/2019, e as modalidades de colaboração premiada autorizadas pelo ordenamento jurídico pátrio.

\section{O PROCESSO PENAL CLÁSSICO}

O Sistema Penal abriga a forma mais grave de intervenção social à disposição do Estado e se orienta em prol da defesa dos bens jurídicos mais relevantes para a sociedade, limitando sua atuação de modo a não provocar danos aos cidadãos além dos necessários à manutenção da ordem social.

O princípio da ultima ratio ${ }^{8}$ recomenda que o Estado evite a criminalização de condutas que podem ser reprimidas de maneira eficaz sem a necessidade de intervenção do Direito Penal.

A tipicidade, além da função de garantia, tem também uma função seletiva, de definir quais condutas poderão sofrer sanções penais. Assim, a especificação de cada tipo penal está associada à proteção de um bem jurídico próprio, que a ameaça da pena respectiva deverá buscar evitar que seja posto em situação de risco. Por exemplo, para proteger a vida, direito fundamental, expresso no caput do artigo $5^{\circ}$ da Constituição da República, o artigo 121 do Código Penal vigente prevê punição para o homicídio.

\footnotetext{
7 ADCs 43, 44 e 54 - Plenário - Rel. Min. Marco Aurélio - por maioria - j. 07.11.2019 (DJe $\mathrm{n}^{\circ}$ 257/2019).

${ }^{8}$ Bitencourt, C. R. Tratado de Direito Penal: Parte-Geral. 26 ${ }^{\text {a }}$ Ed. São Paulo: Saraiva, 2020.
} 
Ocorre que a simples previsão de tipos penais torna-se inócua quando se verifica incapacidade do Estado de punir os autores de condutas típicas, ilícitas e culpáveis. Do momento em que as condutas são praticadas até a possibilidade de imposição da pena na sentença, temos o processo penal.

O processo penal pode ser visto como um conjunto de atos em contraditório. Nele, a proteção de cada bem tutelado especificamente convive com a proteção do direito da defesa.

O Direito Penal define as condutas proibidas, enquanto o Processo Penal regulamenta a investigação dos crimes, o modo como se buscará a verdade sobre os fatos e a responsabilidade criminal, assim como o modo como a decisão judicial deve resolver o conflito entre o interesse do Estado de punir o autor daquela conduta típica, ilícita e culpável e o direito fundamental à liberdade do sujeito investigado.

Entre a identificação da conduta e a aplicação da sanção, há, portanto, um rito a ser cumprido. O Estado precisa jurisdicionalizar sua intenção punitiva, ou seja, submetê-la ao crivo do Judiciário. Do princípio da obrigatoriedade, resultado da interpretação gramatical do artigo 24 do Código de Processo Penal, se infere que aquele que comete crime precisa ser submetido a julgamento:

Art 24. Nos crimes de ação penal pública, esta será promovida por denúncia do Ministério Público, mas dependerá, quando a lei o exigir, de requisição do Ministro da Justiça, ou de representação do ofendido ou de quem tiver qualidade para representá-lo. (grifo nosso)

No modelo garantista brasileiro, não é possível uma sentença penal condenatória sem que o devido processo legal torne certa a autoria e a materialidade do fato imputado.

O CPP vigente, de 1941, foi elaborado durante ditadura, sob vigência da Carta de 1937. Sua exposição de motivos traz a seguinte mensagem: "Não se pode contemporizar com pseudo-direitos individuais em prejuízo do bem comum.”

Entretanto, o inciso LVII do artigo $5^{\circ}$ da Constituição de 1988 expressamente dispõe que "ninguém será considerado culpado até o trânsito em julgado de sentença penal condenatória". Assim, o CPP teve de se adaptar ao texto constitucional, conforme será exposto a seguir. 
Em resumo, podemos afirmar que o processo penal clássico impõe um trâmite para que as condutas previamente definidas como crime recebam a adequada resposta do Sistema Penal. O processo, nesta ótica, nada mais é do que uma garantia.

\section{A PRESUNÇÃO DE INOCÊNCIA ATÉ O TRÂNSITO EM JULGADO}

O processo penal garante ao acusado a oportunidade de se defender sob os ditames do contraditório e da ampla defesa, para que, ao final do processo, os julgadores atinjam um estado de significativa certeza. Garante, ainda, o acesso às instâncias recursais.

Desde 1988, quando a Constituição foi promulgada, até 2009, o art. 283 do Código de Processo Penal, juntamente com os artigos 393 e 594, estabeleciam a prisão em decorrência da condenação:

Art. 283. A prisão poderá ser efetuada em qualquer dia e a qualquer hora, respeitadas as restrições relativas à inviolabilidade do domicílio. (redação original do artigo).

Art. 393. São efeitos da sentença condenatória recorrível: (Revogado pela Lei $\mathrm{n}^{\circ} 12.403$, de 2011). I - ser o réu preso ou conservado na prisão, assim nas infrações inafiançáveis, como nas afiançáveis enquanto não prestar fiança; II - ser o nome do réu lançado no rol dos culpados.

Art. 594. O réu não poderá apelar sem recolher-se à prisão, ou prestar fiança, salvo se for primário e de bons antecedentes, assim reconhecido na sentença condenatória, ou condenado por crime de que se livre solto. (Revogado pela Lei $\mathrm{n}^{\circ} 11.719$, de 2008).

Ainda assim, até 2009, o entendimento do STF era pela possibilidade de prisão somente após condenação em segundo grau. Este entendimento veio a ser superado a partir do julgamento do $\mathrm{HC}$ 84.078/DF ${ }^{9}$, cuja ementa vale ser transcrita:

HABEAS CORPUS. INCONSTITUCIONALIDADE DA
CHAMADA "EXECUÇÃO ANTECIPADA DA PENA". ART. $5^{\circ}$,
LVII, DA CONSTITUIÇÃO DO BRASIL. DIGNIDADE DA
PESSOA HUMANA. ART. 1 ${ }^{\circ}$, III, DA CONSTITUIÇÃO DO
BRASIL.
1. O art. 637 do CPP estabelece que "[o] recurso extraordinário não
tem efeito suspensivo, e uma vez arrazoados pelo recorrido os autos
do traslado, os originais baixarão à primeira instância para a execução
da sentença". A Lei de Execução Penal condicionou a execução da

\footnotetext{
${ }^{9}$ HC 84.078/DF ${ }^{9}$ Plenário, Rel. Min. Eros Grau, por maioria, j. 05/02/2009 (DJE de 26/10/2010).
} 
pena privativa de liberdade ao trânsito em julgado da sentença condenatória. A Constituição do Brasil de 1988 definiu, em seu art. 5, inciso LVII, que "ninguém será considerado culpado até o trânsito em julgado de sentença penal condenatória".

2. Daí que os preceitos veiculados pela Lei n. 7.210/84, além de adequados à ordem constitucional vigente, sobrepõem-se, temporal e materialmente, ao disposto no art. 637 do CPP.

3. A prisão antes do trânsito em julgado da condenação somente pode ser decretada a título cautelar.

4. A ampla defesa, não se a pode visualizar de modo restrito. Engloba todas as fases processuais, inclusive as recursais de natureza extraordinária. Por isso a execução da sentença após o julgamento do recurso de apelação significa, também, restrição do direito de defesa, caracterizando desequilíbrio entre a pretensão estatal de aplicar a pena e o direito, do acusado, de elidir essa pretensão.

5. Prisão temporária, restrição dos efeitos da interposição de recursos em matéria penal e punição exemplar, sem qualquer contemplação, nos "crimes hediondos" exprimem muito bem o sentimento que EVANDRO LINS sintetizou na seguinte assertiva: "Na realidade, quem está desejando punir demais, no fundo, no fundo, está querendo fazer o mal, se equipara um pouco ao próprio delinquente".

6. A antecipação da execução penal, ademais de incompatível com o texto da Constituição, apenas poderia ser justificada em nome da conveniência dos magistrados --- não do processo penal. A prestigiarse o princípio constitucional, dizem, os tribunais [leia-se STJ e STF] serão inundados por recursos especiais e extraordinários e subsequentes agravos e embargos, além do que "ninguém mais será preso". Eis o que poderia ser apontado como incitação à "jurisprudência defensiva", que, no extremo, reduz a amplitude ou mesmo amputa garantias constitucionais. A comodidade, a melhor operacionalidade de funcionamento do STF não pode ser lograda a esse preço.

7. No RE 482.006, relator o Ministro Lewandowsky, quando foi debatida a constitucionalidade de preceito de lei estadual mineira que impõe a redução de vencimentos de servidores públicos afastados de suas funções por responderem a processo penal em razão da suposta prática de crime funcional [art. $2^{\circ}$ da Lei n. 2.364/61, que deu nova redação à Lei n. 869/52], o STF afirmou, por unanimidade, que o preceito implica flagrante violação do disposto no inciso LVII do art. $5^{\circ}$ da Constituição do Brasil. Isso porque --- disse o relator --- "a se admitir a redução da remuneração dos servidores em tais hipóteses, estar-se-ia validando verdadeira antecipação de pena, sem que esta tenha sido precedida do devido processo legal, e antes mesmo de qualquer condenação, nada importando que haja previsão de devolução das diferenças, em caso de absolvição". Daí porque a Corte decidiu, por unanimidade, sonoramente, no sentido do não recebimento do preceito da lei estadual pela Constituição de 1.988, afirmando de modo unânime a impossibilidade de antecipação de qualquer efeito afeto à propriedade anteriormente ao seu trânsito em julgado. A Corte que vigorosamente prestigia o disposto no preceito constitucional em nome da garantia da propriedade não a deve negar 
quando se trate da garantia da liberdade, mesmo porque a propriedade tem mais a ver com as elites; a ameaça às liberdades alcança de modo efetivo as classes subalternas.

8. Nas democracias mesmo os criminosos são sujeitos de direitos. Não perdem essa qualidade, para se transformarem em objetos processuais. São pessoas, inseridas entre aquelas beneficiadas pela afirmação constitucional da sua dignidade (art. $1^{\circ}$, III, da Constituição do Brasil). É inadmissível a sua exclusão social, sem que sejam consideradas, em quaisquer circunstâncias, as singularidades de cada infração penal, o que somente se pode apurar plenamente quando transitada em julgado a condenação de cada qual.

Ordem concedida.

Dada a constatação da sua incompatibilidade com a Constituição Federal, em especial, com a presunção de inocência anunciada expressamente no art. $5^{\circ}$., LVII (v. próxima nota), a redação foi alterada para a seguinte: Art. 283. Ninguém poderá ser preso senão em flagrante delito ou por ordem escrita e fundamentada da autoridade judiciária competente, em decorrência de sentença condenatória transitada em julgado ou, no curso da investigação ou do processo, em virtude de prisão temporária ou prisão preventiva. (Redação dada pela Lei $n^{\circ}$ 12.403, de 2011). $\S 1_{-}^{\circ}$ As medidas cautelares previstas neste Título não se aplicam à infração a que não for isolada, cumulativa ou alternativamente cominada pena privativa de liberdade. (Incluído pela Lei ${ }^{\circ} 12.403$, de 2011). § 2 $2_{-}^{\circ}$ A prisão poderá ser efetuada em qualquer dia e a qualquer hora, respeitadas as restrições relativas à inviolabilidade do domicílio. (Incluído pela Lei

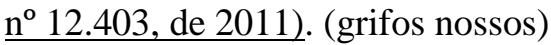

Entretanto, no julgamento do já mencionado Habeas Corpus 126.292/SP, em 17/02/2016, que viria a se tornar paradigma para o novo posicionamento do STF a respeito da possibilidade de prisão do acusado antes do trânsito em julgado da decisão condenatória, o STF passou a aplicar entendimento oposto a esta previsão, afirmando que, após a confirmação da condenação na segunda instância, mesmo cabendo ainda recurso aos Tribunais Superiores, o magistrado pode determinar o início da execução da pena com a consequente prisão do acusado:

CONSTITUCIONAL. HABEAS CORPUS. PRINCÍPIO CONSTITUCIONAL DA PRESUNÇÃO DE INOCENCIA (CF, ART. $5^{\circ}$, LVII). SENTENÇA PENAL CONDENATÓRIA CONFIRMADA POR TRIBUNAL DE SEGUNDO GRAU DE JURISDIÇÃO. EXECUÇÃO PROVISÓRIA. POSSIBILIDADE. 1. A execução provisória de acórdão penal condenatório proferido em grau de apelação, ainda que sujeito a recurso especial ou extraordinário, não compromete o princípio constitucional da presunção de inocência afirmado pelo artigo $5^{\circ}$, inciso LVII da Constituição Federal. 2. Habeas corpus denegado. (grifo nosso)

O Relator, o ministro Teori Zavascki, sustentou que deve haver equilíbrio entre o princípio constitucional de presunção de inocência e a efetividade da função 
jurisdicional penal, de modo a atender a conflitantes valores, caros não apenas aos acusados, mas também à sociedade.

A Ministra Rosa Weber ressalvou que, a seu ver, "se a Constituição, com clareza, em seu texto vincula o princípio da presunção de inocência a uma condenação transitada em julgado, não vejo como possa chegar-se a uma interpretação diversa."

Embora tenha consignando sua discordância, a Ministra decidiu, a partir de então, acompanhar a posição da maioria dos ministros, que entendeu, naquela ocasião, que não haveria violação aos artigos supracitados, por não haver nos Tribunais Superiores discussão sobre os fatos e as provas de autoria e materialidade, visto que essa fase de análise jurídica se encerra na segunda instância.

Nova posição veio a prevalecer em 2019 quando foram a julgamento as Ações Declaratórias de Constitucionalidade (ADC) 43, 44 e $54^{10}$. Desta vez, a maioria se formou a favor do entendimento que a Ministra Rosa Weber consignara em 2016.

Reconheceu-se que a imposição de pena restritiva de liberdade sem o respeito ao devido processo penal mostra-se incompatível com a Constituição e com as Convenções Internacionais sobre Direitos Humanos, tal como registrou em seu voto o Min. Ricardo Lewandowsky:

"a opção do constituinte brasileiro, soberanamente adotada em 1988, foi no sentido de não admitir a prisão antes do trânsito em julgado da sentença condenatória, em virtude das notórias distorções que, desde os tempos coloniais, caracterizam a persecução penal entre nós, branda com os privilegiados e implacável com os desassistidos".

O ministro, que em 2018, julgando o HC 152.856, já proclamara que a Constituição de 1988 "não é uma mera folha de papel, que pode ser rasgada sempre que contrarie as forças políticas do momento", ressaltou, então, que, ao revés,

\footnotetext{
"a Carta Magna possui força normativa suficiente para fazer com seus preceitos, notadamente aqueles que garantem os direitos individuais e coletivos das pessoas, sejam cabalmente observados, ainda que anseios momentâneos, mesmo aqueles tidos como prioritários em um determinado momento histórico - a exemplo do combate à corrupção, que um setor mais mobilizado da sociedade, politicamente motivado, hoje reclama com estridência - requeiram solução diversa".
}

${ }^{10}$ ADCs 43, 44 e 54 - Plenário - Rel. Min. Marco Aurélio - por maioria - j. 07.11.2019 (DJe ${ }^{\circ}$ 257/2019). 
Segundo Lewandowsky "a única saída legítima para qualquer crise, real ou imaginária, em um regime que se pretenda democrático, consiste justamente no incondicional respeito às normas constitucionais. Isso porque não se pode fazer política criminal contra o que dispõe a Constituição, mas sim - e sempre - com amparo nela!"

Cabe transcrever mais um trecho do voto do Ministro:

“...como já diziam os jurisconsultos de antanho, in claris cessat interpretatio. E o texto do inciso LVII do art. $5^{\circ}$ da Carta Magna, ademais, além de ser claríssimo, jamais poderia ser objeto de uma inflexão jurisprudencial para interpretá-lo in malam partem, ou seja, em prejuízo dos acusados em geral.

Por fim, não custa recordar que o art. 30 da Declaração Universal dos Direitos do Homem de 1948, elaborada sob os auspícios da Organização das Nações Unidas e subscrita pelo Brasil - considerada pelos especialistas verdadeiro jus cogens internacional, ou seja, de observância obrigatória por todos os Estados que a assinaram -, consagrou o principio da proibição do retrocesso em matéria de direitos e garantias fundamentais, plenamente aplicável à espécie”.

Embora ainda estejam em curso tentativas de viabilizar a execução da pena de prisão antes do trânsito em julgado, propõe-se aqui um outro caminho: a adoção de fórmulas processuais que agilizem a solução dos litígios criminais sem desrespeitar normas constitucionais e convencionais.

É com esse objetivo que passamos a analisar institutos inspirados na chamada Justiça Criminal Negociada ou Consensual já adotados no Brasil.

\section{JUSTIÇA CRIMINAL CONSENSUAL OU NEGOCIADA}

No Brasil, a permissão da realização de transação em matéria penal veio da Constituição de 1988, que determinou, em seu art. 98, I, a criação dos Juizados Especiais Cíveis e Criminais.

A Lei n. ${ }^{\circ}$ 9.099/95 constituiu um marco no direito penal-processual brasileiro ao estabelecer como objetivos dos processos perante os Juizados Especiais Criminais a busca da reparação do dano à vítima e a aplicação da pena não privativa de liberdade (art. 62). 
Introduziu-se, a partir de três institutos despenalizadores (a Composição Civil, a Transação Penal e a Suspensão Condicional do Processo), um novo paradigma na ordem jurídico-penal nacional: o da justiça criminal consensual ou negociada. A busca de uma solução do conflito passa a sobrepor-se à de uma determinação de mérito.

Neste sentido, o art. 76 da Lei 9099/95 dispõe que: “havendo representação ou tratando-se de crime de ação penal pública incondicionada, não sendo caso de arquivamento, o Ministério Público poderá propor a aplicação imediata de pena restritiva de direitos ou multas, a ser especificada na proposta".

Como apontado na Introdução, antes mesmo de ser instado a se defender, o autor de um crime pode ser beneficiado pelo arquivamento do processo, quando o Ministério Público, nos casos da ação penal pública, entender pela ausência da justa causa. Os Juizados Criminais propiciam, contudo, a possibilidade de o acusado comparecer à audiência de conciliação, antes mesmo do oferecimento da denúncia, colocando-se diante da vítima. Nesta audiência, realizada por um conciliador, busca-se a composição civil do dano.

Em seguida, havendo representação ou tratando-se de crime de ação penal pública incondicionada, os autos do processo são remetidos ao Ministério Público. Este, antes do oferecimento da denúncia, portanto ainda na fase administrativa ou préprocessual, poderá propor um acordo, transacionando o direito de punir do Estado com o direito à liberdade do suposto autor do fato.

Vimos acima que não é possível, em nosso sistema, uma sentença penal condenatória, tornando certa a autoria e a materialidade do fato imputado, sem o devido processo legal, previsto no inciso LIV do artigo $5^{\circ}$ da Constituição.

Segundo o referido inciso, "ninguém será privado da liberdade ou de seus bens sem o devido processo legal", o que pressupõe o contraditório e a ampla defesa, com os meios e recursos a ela inerentes, tal como previsto no inciso seguinte.

Como visto na seção anterior, o inciso LVII do mesmo artigo $5^{\circ}$ da Constituição dispõe que "ninguém será considerado culpado até o trânsito em julgado de sentença penal condenatória", consagrando o brocado latino Nulla culpa sine judicio. 
Além da previsão expressa na Constituição brasileira, o devido processo legal é um direito fundamental do homem consagrado na Declaração Universal dos Direitos Humanos:

Art. $8^{\circ}$ "Todo o homem tem direito a receber dos tribunais nacionais competentes remédio efetivo para os atos que violem os direitos fundamentais que lhe sejam reconhecidos pela constituição ou pela lei”.

A Convenção de São José da Costa Rica dispõe no art. $8^{\circ}$ :

Art. 8﹎ - "Garantias judiciais

1. Toda pessoa terá o direito de ser ouvida, com as devidas garantias e dentro de um prazo razoável, por um juiz ou Tribunal competente, independente e imparcial, estabelecido anteriormente por lei, na apuração de qualquer acusação penal formulada contra ela, ou na determinação de seus direitos e obrigações de caráter civil, trabalhista, fiscal ou de qualquer outra natureza.

(...)"

No caso da transação penal, porém, o suposto autor do fato não reconhece sua culpa ou responsabilidade civil ao aceitar a proposta feita pelo Ministério Público, apenas se submete a uma medida penal para evitar a contingência de vir a ser acusado e processado criminalmente.

A "pena” aplicada na transação penal não tem caráter de sanção penal. Tanto é assim que a própria lei estabelece que a aceitação, pelo autor da infração, da proposta do Ministério Público não importará em caracterização de reincidência nem de maus antecedentes. O acordo não constará da certidão criminal, sendo registrado apenas para impedir que o acusado usufrua novamente do mesmo benefício no prazo de cinco anos, conforme disposto nos parágrafos $4^{\circ}$ e $6^{\circ}$ do art. 76.

Aceita a proposta pelo autor do fato e seu defensor, ela deverá ser encaminhada ao Juiz para apreciação, ou seja, para o controle jurisdicional, que visa a avaliar se a mesma está dentro dos parâmetros legais.

Outro instituto trazido pela Lei 9099/1995, inspirado no nolo contendere, foi a suspensão condicional do processo, que submete o acusado a um período de prova (art. 89, § 1. ${ }^{\circ}$, incisos I, II, III, IV, Lei 9.099/1995), que tem por finalidade evitar a prolação de uma sentença, por meio do sobrestamento da ação penal estabelecido de forma consensual entre a acusação e a defesa ${ }^{11}$.

\footnotetext{
${ }^{11}$ Grinover, A. P. et al., Juizados especiais criminais: comentários à lei 9.099, de 26.09.1995. São Paulo: Editora Revista dos Tribunais, 2005, p. 344.
} 
Este instituto, também denominado "sursis processual" ou "sursis antecipado"12, não se confunde com a suspensão condicional da pena, que pressupõe a existência de uma sentença condenatória. Tal como na transação penal, o suposto autor do fato não reconhece sua culpa.

Sem base legal ou amparo constitucional, o artigo 18 da Resolução CMNP 181/2017 estabelecera a possibilidade de o Ministério Público propor ao investigado acordo de não persecução penal para crimes sem violência ou ameaça com pena mínima de até quatro anos. Com a entrada em vigor da Lei 13.964/2019, o CPP passou a contemplar, no seu novel artigo 28-A, esta possibilidade.

Este dispositivo, em seu caput a seguir transcrito, manteve a previsão constante da mencionada Resolução no sentido de que o acordo de não persecução penal exige a confissão do investigado:

"Art. 28-A. Não sendo caso de arquivamento e tendo o investigado confessado formal e circunstancialmente a prática de infração penal sem violência ou grave ameaça e com pena mínima inferior a 4 (quatro) anos, o Ministério Público poderá propor acordo de não persecução penal, desde que necessário e suficiente para reprovação e prevenção do crime, mediante as seguintes condições ajustadas cumulativa e alternativamente:

I - reparar o dano ou restituir a coisa à vítima, exceto na impossibilidade de fazê-lo;

II - renunciar voluntariamente a bens e direitos indicados pelo Ministério Público como instrumentos, produto ou proveito do crime;

III - prestar serviço à comunidade ou a entidades públicas por período correspondente à pena mínima cominada ao delito diminuída de um a dois terços, em local a ser indicado pelo juízo da execução, na forma do art. 46 do Decreto-Lei n 2.848 , de 7 de dezembro de 1940 (Código Penal);

IV - pagar prestação pecuniária, a ser estipulada nos termos do art. 45 do Decreto-Lei no 2.848, de 7 de dezembro de 1940 (Código Penal), a entidade pública ou de interesse social, a ser indicada pelo juízo da execução, que tenha, preferencialmente, como função proteger bens jurídicos iguais ou semelhantes aos aparentemente lesados pelo delito; ou

V - cumprir, por prazo determinado, outra condição indicada pelo Ministério Público, desde que proporcional e compatível com a infração penal imputada.

Outra possibilidade de negociação no processo penal é a colaboração premiada. Aras $(2015)^{13}$ aponta quatro espécies de colaboração premiada, quais sejam: a) “delação

\footnotetext{
${ }^{12}$ Capez, F. Curso de Processo Penal, 28 ${ }^{\text {a }}$. Ed. São Paulo: Saraiva, 2021
}

${ }^{13}$ ARAS, V. A técnica da colaboração premiada. 2015. 
premiada"; b) "colaboração para libertação"; c) "colaboração para localização e recuperação de ativos"; e d) "colaboração preventiva".

Destas, a modalidade mais difundida é a delação, também chamada de chamamento de corréu, que é aquela em que o colaborador aponta as outras pessoas implicadas no crime e descreve o papel delas na ocorrência investigada.

No caso da simples confissão, a declaração do agente não implica terceiros, ou seja, gera efeitos jurídicos apenas para aquele que a pratica. Na delação premiada é insuficiente que o acusado confesse sua concorrência na consecução do crime. Deverá, também, delatar os codelinquentes que concorreram para a prática do mesmo crime.

No ordenamento jurídico pós Constituição de 1988, a delação premiada foi instituída, inicialmente, pela Lei $\mathrm{n}^{\circ}$ 8.072/90 (Lei de Crimes Hediondos, que regulamentou o artigo $5^{\circ}$, XLIII, CF/1988).

$\mathrm{O}$ art. $7^{\circ}$ daquele diploma legislativo acrescentou o $\S 4^{\circ}$ ao artigo 159 do Código Penal que trata da extorsão mediante sequestro, a saber: "Se o crime é cometido por quadrilha ou bando, o coautor que denunciá-lo à autoridade, facilitando a libertação do sequestrado, terá sua pena reduzida de um a dois terços”.

Estabeleceu-se, também, a mesma redução de um a dois terços da pena do participante ou associado de quadrilha envolvida na prática de crimes hediondos, tortura, tráfico de drogas e terrorismo, que denunciasse à autoridade o grupo, permitindo seu desmantelamento (art. $8^{\circ}$, parágrafo único, Lei 8.072/1990).

Com a Lei 9.080/1995, semelhante previsão foi incluída no $\S 2^{\circ}$ do Art. 25 da Lei do Colarinho Branco (Lei 7492/1986):

Art. $25, \S 2^{\circ}$ "Nos crimes previstos nesta Lei, cometidos em quadrilha ou coautoria, o coautor ou partícipe que através de confissão espontânea revelar à autoridade policial ou judicial toda a trama delituosa terá a sua pena reduzida de um a dois terços".

Também foi incluída a previsão da delação premiada para crimes contra o Sistema Financeiro Nacional e contra a ordem tributária (art. 16, parágrafo único, da Lei 8.137/1990, incluído pela Lei 9.080/1995) e crimes praticados por organização criminosa (art. $6^{\circ}$, Lei 9.034/1995).

Posteriormente, o $§ 4^{\circ}$ do Art. 159 do Código Penal (Decreto-Lei 2.848/40) foi alterado pelo artigo $1^{\circ}$ da Lei 9.269/96, recebendo a nova redação: "Se o crime é 
cometido em concurso, o concorrente que o denunciar à autoridade, facilitando a libertação do sequestrado, terá sua pena reduzida de um a dois terços".

No artigo $1^{\circ}, \S 5^{\circ}$, da Lei 9.613/98 (Lei de combate à lavagem de dinheiro) havia a seguinte previsão:

A pena será reduzida de um a dois terços e começará a ser cumprida em regime aberto, podendo o juiz deixar de aplicá-la, ou substituí-la por pena restritiva de direitos, se o autor, coautor ou partícipe colaborar espontaneamente com as autoridades, prestando esclarecimentos que conduzam à apuração das infrações penais e de sua autoria à localização dos bens, direitos ou valores objeto do crime.

Observe-se que a Lei 9.613/1998 já significara um reforço ao instituto, ao prever prêmios mais estimulantes ao colaborador, tais como a possibilidade de condenação a regime menos gravoso (aberto ou semiaberto), a substituição da pena privativa de liberdade por restritiva de direitos e até o mesmo perdão judicial $\left(\operatorname{art.} 1^{\circ}, \S 5^{\circ}\right.$, Lei 9.613/1998).

Atualmente, com a redação conferida pela Lei 12.683/2012, a redação é a seguinte:

A pena poderá ser reduzida de um a dois terços e ser cumprida em regime aberto ou semiaberto, facultando-se ao juiz deixar de aplicá-la ou substituí-la, a qualquer tempo, por pena restritiva de direitos, se o autor, coautor ou partícipe colaborar espontaneamente com as autoridades, prestando esclarecimentos que conduzam à apuração das infrações penais, à identificação dos autores, coautores e partícipes, ou à localização dos bens, direitos ou valores objeto do crime.

Assim, no crime de lavagem de dinheiro, sem prejuízo de ser causa de redução de pena, a colaboração é também causa obrigatória de imposição de regime aberto, e autoriza a substituição da pena privativa de liberdade por restritiva de direitos.

A Lei 9.807/1999, que trata da proteção de testemunhas (arts. 13 e 14), também previu prêmios diversos ao colaborador, enquanto a Lei 11.343/2006 (trata-se da Lei antitóxico, que revogou a Lei 10.409/02), previu a colaboração premiada para crimes de tráfico de drogas (art. 41).

Por fim, a Lei 12.850/2013, que revogou a Lei 9.034/1995 (Lei de Prevenção ao Crime Organizado), definiu o conceito de organização criminosa, dispôs sobre a investigação criminal e meios de obtenção da prova e estabeleceu novas regras para a colaboração premiada, no âmbito do enfrentamento de organizações criminosas. 
E o STF reconheceu a constitucionalidade de acordos de colaboração premiada ${ }^{14}$ firmados com base nas Convenções de Palermo (art. 26 do Decreto 5.015/2004) e de Mérida (art. 37 do Decreto 5.687/2006).

\section{O JUIZ DAS GARANTIAS}

Por mais minuciosa que venha a ser a regulamentação dos parâmetros legais para a negociação das penas, é indiscutível que a justiça criminal negociada abre a possibilidade de atribuição de pena sem o exercício do contraditório no curso do processo penal. O tamanho da redução da pena obtida em cada caso nunca tem o valor correspondente à proteção da liberdade que o processo é, em princípio, suposto garantir ao acusado.

A negociação inclui integralmente a possibilidade de o acusado abrir mão do seu direito a ampla defesa. Podem induzi-lo ilegitimamente a abrir mão desse direito fatores tais como os custos embutidos na ameaça da duração excessiva do processo (ou de eventuais medidas cautelares), a ampliação do estigma associado à condição de réu e assim por diante.

À esses fatores juntam-se os aspectos inerentes a uma negociação com autoridades poderosas e com experiência na negociação de penas.

A inserção da figura do juiz das garantias no Código de Processo Penal pela Lei $13.694 / 2019^{15}$ poderá vir a limitar a influência desses fatores:

Art. $3^{\circ}$ O Decreto-Lei $n^{\circ} 3.689$, de 3 de outubro de 1941 (Código de Processo Penal), passa a vigorar com as seguintes alterações:

'Art. $3^{\circ}$-A. O processo penal terá estrutura acusatória, vedadas a iniciativa do juiz na fase de investigação e a substituição da atuação probatória do órgão de acusação.’

'Art. $3^{\circ}$-B. O juiz das garantias é responsável pelo controle da legalidade da investigação criminal e pela salvaguarda dos direitos individuais cuja franquia tenha sido reservada à autorização prévia do Poder Judiciário, competindo-lhe especialmente:

(...)

\footnotetext{
${ }^{14} \mathrm{HC} \mathrm{n}^{\circ}$ 90.688, Primeira Turma, Min. Ricardo Lewandowsky, julgado em 12/02/2008, DJe 25-04-2008.

${ }^{15}$ Suspensa por força da decisão cautelar proferida pelo Ministro Luiz Fux, em 22/01/2020, nas Ações Diretas de Inconstitucionalidade (ADIs) ns 6298, 6299, 6300 e 6305.
} 
XVII - decidir sobre a homologação de acordo de não persecução penal ou os de colaboração premiada, quando formalizados durante a investigação;

XVIII - outras matérias inerentes às atribuições definidas no caput deste artigo.

(grifo nosso)

A atuação do juiz das garantias poderá propiciar maior equilíbrio entre os anseios da sociedade e os direitos dos indivíduos. Sua presença no processo de negociação desde o início pode limitar as pressões sobre os acusados, garantindo que eventuais acordos sobre penas venham a ser firmados com maior grau de consciência por aqueles que livremente optem por renunciar ao devido processo penal garantido pela constituição.

\section{CONCLUSÃO}

O sistema judiciário penal não tem unicamente a finalidade de garantir os direitos fundamentais dos acusados. Tem também o propósito de punir os responsáveis pelos crimes.

A legitimidade do sistema penal pressupõe a conformidade com princípios e garantias típicas do Estado de Direito.

O caminho da justiça consensual oferece a possibilidade de maior rapidez na solução de litígios criminais sem desrespeitar garantias fundamentais, sendo porém salutar o controle judicial de modo a mitigar o risco de abusos por parte da acusação.

\section{REFERÊNCIAS:}

ARAS, Vladimir. A Técnica da Colaboração Premiada. 2015. Disponível em: https://vladimiraras.blog/2015/01/07/a-tecnica-de-colaboracao-premiada. Acesso em 22-2-2021.

BITENCOURT, Cezar Roberto. Tratado de Direito Penal: Parte-Geral. 26a . Ed. São Paulo: Saraiva, 2020.

BRASIL. Lei $N^{\circ} 7.492$, de 16 de junho de 1986. Define os crimes contra o sistema financeiro nacional. 
BRASIL. Lei $\mathrm{N}^{\mathrm{o}}$ 8.072, de 25 de julho de 1990. Dispõe sobre os crimes hediondos. Disponível em http://www.planalto.gov.br/ccivil_03/leis/18072.htm Acesso em: 28-02-2019.

BRASIL. Lei No 9.034, de 3 de maio de 1995. Dispõe sobre a prevenção e repressão de ações praticadas por organizações criminosas. Disponível em http://www.planalto.gov.br/ccivil_03/leis/L9034.htm. Acesso em: 28-02-2019.

BRASIL. Lei N ${ }^{\circ}$ 9.099, de 26 de setembro de 1995. Dispõe sobre os Juizados Especiais Cíveis e Criminais. Disponível em http://www.planalto.gov.br/ccivil_03/leis/L9099.htm. Acesso em: 28-02-2019.

BRASIL. Lei $\mathrm{n}^{\mathrm{o}}$ 9.605, de 12 de fevereiro de 1998. Dispõe sobre as sanções penais e administrativas derivadas de condutas e atividades lesivas ao meio ambiente. Disponível em: http://www.planalto.gov.br/ccivil_03/leis/19605.htm. 1998b Acesso em: 2-012020.

BRASIL. Lei n 9.613, de 3 de março de 1998. Dispõe sobre os crimes de "lavagem" ou ocultação de bens, direitos e valores; a prevenção da utilização do sistema financeiro para os ilícitos previstos nesta Lei; cria o Conselho de Controle de Atividades Financeiras - COAF. Disponível em: http://www.planalto.gov.br/ccivil_03/leis/19613.htm. 1998b. Acesso em: 28-022019.

BRASIL. Lei $\mathrm{n}^{\circ}$ 9.714, de 25 de novembro de 1998. Altera dispositivos do Decreto-Lei $\mathrm{n}^{\mathrm{o}} 2.848$, de 7 de dezembro de 1940 - Código Penal. Disponível em: http://www.planalto.gov.br/ccivil_03/leis/19714.htm. 1998a Acesso em: 28-022019.

BRASIL. Lei N ${ }^{\circ}$ 9.807, de 13 de julho de 1999. Estabelece normas para a organização e a manutenção de programas especiais de proteção a vítimas e a testemunhas ameaçadas, institui o Programa Federal de Assistência a Vítimas e a Testemunhas Ameaçadas e dispõe sobre a proteção de acusados ou condenados que tenham voluntariamente prestado efetiva colaboração à investigação policial e ao processo criminal. Disponível em http://www.planalto.gov.br/ccivil_03/leis/L9807.htm. Acesso em: 28-02-2019. 
BRASIL. Lei $\mathrm{N}^{\mathrm{o}}$ 11.343, de 23 de agosto de 2006. Institui o Sistema Nacional de Políticas Públicas sobre Drogas - Sisnad; prescreve medidas para prevenção do uso indevido, atenção e reinserção social de usuários e dependentes de drogas; estabelece normas para repressão à produção não autorizada e ao tráfico ilícito de drogas. Disponível em http://www.planalto.gov.br/ccivil_03/_ato20042006/2006/lei/111343.htm Acesso em: 28-02-2019

BRASIL. LEI $\mathrm{N}^{\mathrm{o}} 12.850$, de 2 de agosto de 2013 . Disponível em http://www.planalto.gov.br/ccivil_03/_Ato2011-2014/2011/Lei/L12850.htm Acesso em: 28-02-2019.

BRASIL. Lei $\mathrm{n}^{\circ}$ 12.683, de 9 de julho de 2012. Torna mais eficiente a persecução penal dos crimes de lavagem de dinheiro. Disponível em: www.planalto.gov.br/ccivil_03/_ato2011-2014/2012/lei/112683.htm. Acesso em: 28-02-2019.

BRASIL. Lei n ${ }^{o}$ 13.964/2019, de 24 de dezembro de 2019. Aperfeiçoa a legislação penal e processual penal. Disponível em: http://www.planalto.gov.br/ccivil_03/_ato2019-2022/2019/lei/L13964.htm Acesso em: 2-01-2020.

BRASIL, Deilton Ribeiro. A garantia do Princípio Constitucional da Presunção de Inocência (ou de não-culpabilidade): um diálogo com os direitos e garantias fundamentais. Revista de Direitos Brasileira, São Paulo, v. 15, n. 6, pp.376-398, 2016.

CAPEZ, Fernando. Curso de Processo Penal, 28ª Ed. São Paulo: Saraiva, 2021.

GRINOVER, Ada Pelegrini; GOMES FILHO, Antônio Magalhães; FERNANDES, Antonio Scarance; GOMES, Luiz Flávio. Juizados especiais criminais: comentários à lei 9.099, de 26.09.1995. São Paulo: Editora Revista dos Tribunais, 2005.

LOPES JR., Aury. Direito processual penal e sua conformidade constitucional - v. 1 . $17^{\mathrm{a}}$. Ed. Rio de Janeiro: Lumen Juris, 2020.

ROSA, Alexandre Morais da; SILVEIRA FILHO, Sylvio Lourenço da. Medidas compensatórias da demora jurisdicional: a efetivação do direito fundamental à duração razoável do processo penal. Rio de Janeiro: Lumen Juris, 2014. 
Revista Eletrônica de Direito Processual - REDP.

Rio de Janeiro. Ano 16. Volume 23. Número 1. Janeiro a Abril de 2022

Periódico Quadrimestral da Pós-Graduação Stricto Sensu em Direito Processual da UERJ

Patrono: José Carlos Barbosa Moreira (in mem.). ISSN 1982-7636. pp. 482-501

www.redp.uerj.br

SOARES, Maurício Negri; RORATO, Izabella Freschi. Garantia constitucional de presunção de inocência e a condenação penal em segundo grau. Revista de Direito Brasileira, v.19, n.8, p. 366-381, 2018. 